\title{
Comparison of Cohen and Lich-Gregoir ureteral reimplantation in the surgical management of primary unilateral vesicoureteral reflux in children
}

\author{
(D) Cemil Aydin' \\ (iD)Ali Akkoc ${ }^{2}$ \\ Damazan Topaktas ${ }^{3}$ \\ (iD) Aykut Bugra Senturk ${ }^{1}$ \\ (iD) Zeynep Banu Aydin ${ }^{4}$ \\ (D) Ahmet Ürkmez ${ }^{3}$ \\ (D) Muhammet Yaytokgil
}

1. Department of Urology, Hitit University School of Medicine, Training and Research Hospital, Corum, Turkey. 2. Department of Urology, Alaaddin Keykubat University School of Medicine, Training and Research Hospital, Alanya, Turkey. 3. Department of Urology, Haydarpaşa Numune Training and Research Hospital, İstanbul, Turkey. 4. Department of Radiology, Hitit University School of Medicine, Training and Research Hospital, Corum, Turkey.

http://dx.doi.org/10.1590/1806-9282.66.4.424

\section{SUMMARY}

OBJECTIVE: Vesicoureteral reflux (VUR) represents one of the most significant risk factors for acute pyelonephritis in children. Various intravesical and extravesical techniques have been described for the surgical correction of VUR. The aim of our study was to compare the results of open intravesical and extravesical procedures for unilateral primary VUR in children.

METHODS: Between January 2012 and August 2018, 38 children with primary VUR who underwent open ureteral reimplantation surgery were retrospectively reviewed. The Cohen (intravesical) and the Lich-Gregoir (extravesical) approach were grouped as groups $A$ and $B$, respectively. The groups were compared for age, gender, preoperative reflux grade, presence of lower urinary tract symptoms, operation time, discomfort and pain, analgesic requirements, duration of hematuria, postoperative complications, and hospital stay. All the parameters were statistically compared.

RESULTS: There were 38 patients in this study. Group A had 18 patients, and group B had 20 patients. The mean operative time was significantly shorter in group $B$ than in group $A$. The mean hospital stay was also shorter in group $B$. The urethral foley stay period was $4.7 \pm 0.9$ days $2 \pm 0$ days $\left(p=0.000^{*}\right)$, respectively, for group $A$ and $B$. Macroscopic hematuria was seen in group A. The objective pain scale was worse after intravesical surgery. Analgesic requirements were higher in group $A(p=0.131)$.

CONCLUSION: Intravesical and extravesical ureteroneocystostomy methods are equally successful and feasible in the treatment of primary unilateral VUR. The Cohen technique is associated with a longer and more painful hospital stay, gross hematuria, and longer operative time, compared to the Lich-Gregoir technique.

KEYWORDS: Vesicoureteral reflux. Ureter/surgery. Pain measurement. Replantation.

DATE OF SUBMISSION: 12-Oct-2019

DATE OF ACCEPTANCE: 10-Nov-2019

CORRESPONDING AUTHOR: Cemil Aydin

Hitit University School of Medicine, Training and Research Hospital, Corum, Turkey

Tel/Fax: +90 3642193000

E-mail: cemilaydin78@yahoo.com.tr 


\section{INTRODUCTION}

Vesicoureteral reflux (VUR) is described as urinary reflux from the bladder to the upper urinary tract. In the treatment of VUR, various intravesical and extravesical techniques have been described. Among these, the Cohen and Lich-Gregoir techniques are the most commonly used in published data. The most concerning issue in VUR is still nephropathy with renal scarring and subsequent hypertension leading to end-stage renal disease ${ }^{1}$. The main purpose of any treatment is to prevent renal damage. Although conservative treatment using antibiotic prophylaxis is widely accepted, most patients with reflux do not develop renal damage and do not require any treatment ${ }^{2,3}$. Each method has specific advantages and disadvantages. In both techniques, the purpose is to lengthen the intramural part of the ureter by a submucosal embedding of the ureter. Currently, success rates vary between $92 \%$ and $98 \%$ for open ureteral reimplantation ${ }^{2}$. There have been perfect research on ureteral reimplantation aiming to define the advantages and disadvantages of each technique; however, there are insufficient studies comparing both techniques in the literature. In our study, our purpose is to compare the results of extravesical (Lich-Gregoir) and intravesical (Cohen) techniques for unilateral primary VUR in children.

\section{METHODS}

In a tertiary academic center, 38 children with primary unilateral VUR who underwent open ureteral

\section{FIGURE 1}

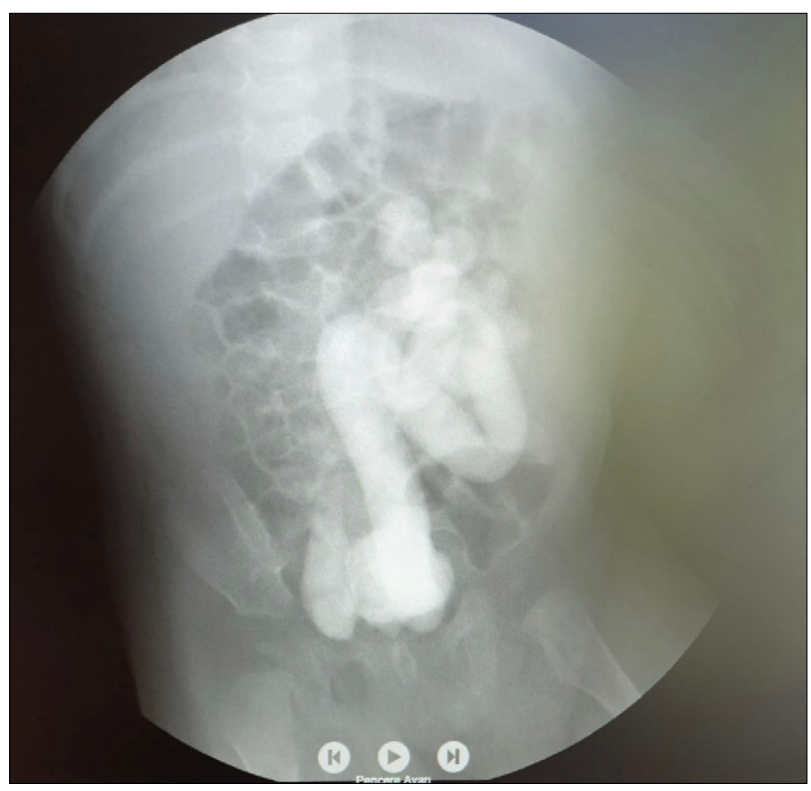

reimplantation surgery were included in this retrospective study between January 2012 and August 2018. Local ethics committee approval and written informed consent were obtained from all participants. The present study conforms to the principles of the Declaration of Helsinki. The exclusion criteria included bilateral ureteroneocystostomy (UNC), need for ureteral tapering, repeat procedures, megaureter, and a diagnosis of neurogenic bladder. The Cohen procedure was attributed to group A, and the Lich-Gregoir procedure to group B. Conventional voiding cystourethrography (VCUG) including two fillings was used for the evaluation of the patients (Figure 1). Reflux was classified as grades I-V according to the International Classification System of the International Reflux Study Committee ${ }^{4}$. The indication for ureteral reimplantation (intravesical or extravesical) was similar, and the risk classification was made according to the EAU / ESPU guidelines ${ }^{5}$. Open surgery indications were recurrence of VUR after endoscopic injection, symptomatic high-grade reflux refractory to conservative treatment, complications due to antibiotics, progressive renal scarring, reflux nephropathy, and parental preference. The bladder was evaluated by cystoscopy before surgery (Figure 2). Renal scans were performed in all patients. We evaluated the clinical data of both groups, including age, gender, preoperative reflux grade, presence of lower urinary tract symptoms (LUTS), operation time, discomfort and pain, analgesic requirements, duration of hematuria, postoperative complications and hospital stay.

\section{FIGURE 2}

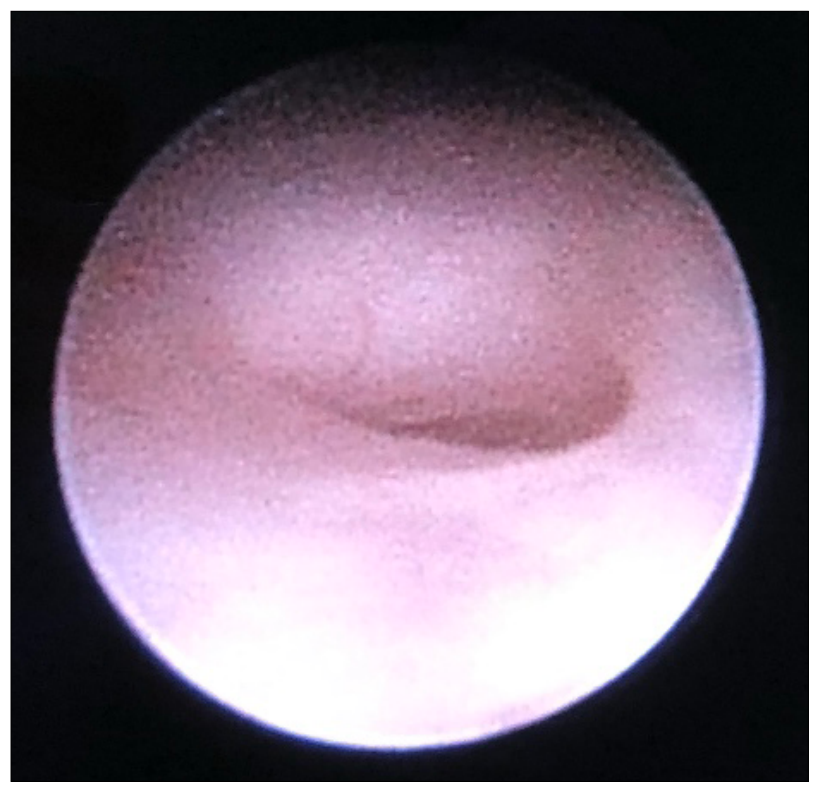


Anticholinergic drug usage and the presence of LUTS were also documented. Patients who had LUTS in the preoperative period received urotherapy initially. The success of the surgery was identified by the absence of reflux via VCUG six months after the surgery. All the parameters were statistically compared.

\section{Statistical analysis}

Statistical analysis was performed using IBM SPSS Statistics ver. 21 (IBM Co., USA). The Student t-test and Shapiro Wilks tests were applied to compare the parameters of each group. In this study, $p<0.05$ was considered statistically significant.

\section{Ethical issues}

Diyarbakır Gazi Yaşargil Training and Research Hospital Ethics Committee, Turkey, approved this study.

\section{RESULTS}

There were 38 patients (male/female, 13/25) in this study. Group A included 18 patients and group B, 20. Demographic data are shown in Table 1. The mean ages of groups A and B were 3.4 \pm 1.8 (1-7) years and $5.5 \pm 2.9(2-9)$, respectively $\left(\mathrm{p}=0.012^{*}\right)$. The mean reflux grades in groups A and B were similar, 3.7 \pm 0.8 (range 3-5) and 3.9 \pm 0.8 (range 3-5), respectively $(\mathrm{p}=$
0.640). The split ipsilateral renal function (DMSA) was also similar for groups A and B, $39.3 \pm 4.6 \%$ vs. $38.6 \pm 4.7 \%$, respectively $(p=0.658)$. There was no statistically significant difference between groups A and $B$ in terms of prior endoscopic injection (Group A 8/18; Group B $7 / 20, p=0.811$ ). The operative and postoperative data are shown in Table 2. The mean operative time of group B was significantly shorter than that of group A ( $85 \pm 11.4$ min vs. $72.6 \pm 10.4 \mathrm{~min}$, respectively $\left.\mathrm{p}=0.001^{*}\right)$. The mean hospital stay was also shorter in group B ( $2 \pm 0.4$ days and $4.6 \pm 0.9$ days, respectively, $\left.\mathrm{p}=0.000^{*}\right)$. The urethral foley stay period was $4.7 \pm 0.9$ and $2 \pm 0$ days ( $39.3 \pm 4.6 \%$ vs. $38.6 \pm 4.7 \%$ ), respectively, for groups A and B. Gross hematuria was observed only in group A, lasting for a mean of $2.5 \pm 1.3$ days $\left(p=0.000^{*}\right)$. The objective pain scale (OPS) was worse after intravesical ureteral reimplantation $(5.7 \pm 1.4$ vs. $4.6 \pm 1.2$, respectively, $\left.\mathrm{p}=0.011^{*}\right)$. However, there was no statistically significant difference between groups A and B regarding the mean need for analgesics (96.2 $\pm 59.4 \mathrm{mg}$. vs. 73.6 $\pm 26.1 \mathrm{mg}$., respectively, $\mathrm{p}=0.131$ ). The mean follow-up times (Table 3 ) of the groups were similar (29.9 \pm 18.9 months vs. $28.4 \pm 17.3$ months, respectively, $\mathrm{p}=0.801$ ). No intraoperative complications were observed in both groups. We did not encounter any major postoperative complications such as febrile urinary tract infections or pyelonephritis, and severe hydronephrosis during the follow

TABLE 1. DEMOGRAPHIC DATA

\begin{tabular}{|c|c|c|c|}
\hline & Group $A(N=18)$ & Group $B(N=20)$ & $\mathrm{P}$ \\
\hline & Mean \pm SD & Mean $\pm S D$ & \\
\hline Age (years) & $3,4 \pm 1,8$ & $5,5 \pm 2,9$ & $0,012^{*}$ \\
\hline Sex (Male/Female) (n) & $6 / 12$ & $7 / 13$ & 0,538 \\
\hline Kidney function (percent) & $39,3 \pm 4,6$ & $38,6 \pm 4,7$ & 0,658 \\
\hline Reflux grade & $3,7 \pm 0,8$ & $3,9 \pm 0,8$ & 0,640 \\
\hline Prior endoscopic injection (n) & $8 / 18$ & $7 / 20$ & 0,811 \\
\hline
\end{tabular}

Independent Student t-test ${ }^{*} \mathrm{p}<0.05$

TABLE 2. OPERATIVE AND POSTOPERATIVE DATA

\begin{tabular}{|c|c|c|c|}
\hline & Group A $(N=18)$ & Group B $(N=20)$ & $\mathrm{P}$ \\
\hline & Mean $\pm S D$ & Mean $\pm S D$ & \\
\hline Operation time (minutes) & $85 \pm 11,4$ & $72,6 \pm 10,4$ & $0,001^{\star}$ \\
\hline Hospital stay (days) & $4,6 \pm 0,9$ & $2 \pm 0,4$ & $0,000^{*}$ \\
\hline Urethral foley stay (days) & $4,7 \pm 0,9$ & $2 \pm 0$ & $0,000^{*}$ \\
\hline Objective pain scale (OPS) & $5,7 \pm 1,4$ & $4,6 \pm 1,2$ & $0,011^{\star}$ \\
\hline Gross hematuria (days) & $2,5 \pm 1,3$ & 0 & $0,000^{*}$ \\
\hline Analgesic requirement (mg) & $96,2 \pm 59,4$ & $73,6 \pm 26,1$ & 0,131 \\
\hline
\end{tabular}

Independent Student t-test ${ }^{*} \mathrm{p}<0.05$ 
up. Afebrile cystitis with positive urine culture was observed in a total of three children in up to 1 year postoperatively in group A. No reflux persistency was observed 1 year after ureteral reimplantation, in both groups.

\section{DISCUSSION}

Vesicoureteral reflux is the most common uropathy in children ${ }^{6}$. Although a spontaneous resolution is common in primary reflux, surgical intervention may be required in persistent reflux, recurrent pyelonephritis, renal scar, or febrile urinary tract infection (UTI) patients. To correct reflux, both intravesical and extravesical approaches are highly successful and reduce the occurrence of febrile UTI ${ }^{6,7}$. Currently, success rates range between $92 \%$ and $98 \%$ for open ureteral reimplantation ${ }^{2}$. In the last ten years, a decrease in the incidence of ureteral reimplantation has been observed in the world. This may be due to a reduction in the number of VCUGs performed and an increase in endoscopic interventions for the treatment of primary VUR ${ }^{8}$. Endoscopic therapies are associated with lower patient morbidity and, possibly, lower costs ${ }^{9}$. Extravesical reimplantation is generally used in Canada and Europe ${ }^{6,10,11}$. However, intravesical reimplantation has become more popular for unilateral VUR in the United States ${ }^{6}$. In recent years, the use of minimally invasive techniques in urology has increased. In the literature, laparoscopic and robotic ureteral reimplantation have equivalent success rates to open surgery ${ }^{12}$. Both intravesical and extravesical techniques have excellent success rates of over $90 \%$ to correct VUR, and both these techniques have their own advantages and disadvantages. Most studies have evaluated the advantages and disadvantages of these techniques, retrospectively ${ }^{6,10,11}$.

In general, the intravesical approach is thought to be more invasive than the extravesical because of the need to open the bladder ${ }^{6,10,11}$. Macroscopic hematuria is a typical postoperative finding that sometimes requires long-term monitoring and catheterization ${ }^{6-11}$. In our study, hematuria was not seen in group $\mathrm{B}$, but we observed a mean duration of gross hematuria of $2.5 \pm 1.3$ days in group A. It is thought that bladder incision is responsible for hematuria, postoperative pain, and bladder spasms ${ }^{13}$. Ellsworth et al. ${ }^{11}$ reported that the extravesical technique causes fewer episodes of bladder spasm and is less painful than the intravesical technique.

Chen et al. ${ }^{14}$ compared three different surgical techniques: open intravesical, open extravesical, and laparoscopic extravesical. They also included bilateral VUR patients in their study, in contrast to ours. They found that the mean operative time was significantly shorter in the Lich-Gregoir group than in the Cohen group, 58 minutes vs. 113 minutes, respectively ( $p$ $<0.001)$. In addition, the hospital stay was also longer for the Cohen group than for the Lich-Gregoir, 4.9 days vs. 3.0 days $(p<0.05)^{14}$. In our study, the mean hospital stay was also shorter in group $B$, in agreement with the literature $(1.2 \pm 0.8$ and $5.8 \pm 1$ days, respectively, $p$ $=0.007)$. We think extravesical ureteral reimplantation appears to be more advantageous than intravesical ureteral reimplantation in terms of hospital stay. Esposito et al. compared the open Cohen technique, the endoscopic subureteric injection procedure, and the laparoscopic extravesical ureteral reimplantation, according to Lich-Gregoir. They reported that the operative time in the Cohen group was 109 minutes. Although the success rates of these three techniques were similar, the Cohen group had a longer hospital stay and higher analgesic requirements ${ }^{15}$. In our study, the mean operative time was significantly shorter in group B than in group A, in line with these studies (85 \pm 11.4 minutes vs. $72.6 \pm 10.4$ minutes, respectively $\left.\mathrm{p}=0.001^{*}\right)$.

Postoperative pain and analgesic demand are other important parameters. Oswald et al. ${ }^{16}$ reported that the extravesical approach needs less pain medication

TABLE 3. FOLLOW UP

\begin{tabular}{l|l|l|l} 
& Group A $(\mathrm{N}=18)$ & Group B $(\mathrm{N}=20)$ & $\mathrm{P}$ \\
& Mean \pm SD & Mean \pm SD & \\
\hline Follow up (months) & $29,9 \pm 18,9$ & $28,4 \pm 17,3$ & 0,801 \\
\hline Afebrile cystitis $(\mathrm{n}, \%)$ & $3(16.6 \%)$ & - & 0,080 \\
\hline reflux persistency & - & - & \\
\hline hydronephrosis & - & - & \\
\hline pyelonephritis & - & - & \\
\hline
\end{tabular}

Independent Student t-test ${ }^{*} \mathrm{p}<0.05$ 
and anticholinergics postoperatively. Arlen et al. ${ }^{17}$ found no difference between surgical techniques and analgesic demand. Harel et al. ${ }^{18}$ compared the results of open intravesical ureteral reimplantation and robotic extravesical ureteral reimplantation and found that robotic extravesical ureteral reimplantation has less analgesic demand and postoperative pain than open ureteral reimplantation. In their study, in the robotic surgery group, $87 \%$ of the patients were discharged from the hospital on the operation day. In our study, OPS scores were higher in group A (5.7 \pm 1.4 vs. $4.6 \pm 1.2$, respectively, $\left.\mathrm{p}=0.011^{*}\right)$, as was the need for analgesics ( $96.2 \pm 59.4 \mathrm{mg}$. vs. $73.6 \pm 26.1 \mathrm{mg}$., respectively, $p=0.131$ ); however, these were not statistically significant. The extravesical approach is less painful than intravesical approaches.

Routine stent placement after the Cohen technique is debatable in the literature. Most authors still use stents after Cohen ureteral reimplantation, while others do not ${ }^{19,20}$. Uvin et al. ${ }^{20}$ reported that the use of temporary ureteral double $\mathrm{J}$ stenting did not cause postoperative infections in children. We did not insert a double $\mathrm{J}$ stent after the Cohen technique routinely.

The effect of endoscopic injections prior to open UNC on success rates is another argument in the literature. Lee et al. ${ }^{21}$ reported that there were no significant differences in operative time, hospitalization time, postoperative complications, and success rates among open ureteral reimplantation techniques after previous failed endoscopic injection for primary VUR. Previous endoscopic injection surgery had no negative effect on our surgical results.

The main limitation of our study is the retrospective analysis of patient's data. However, there are a limited number of studies comparing these two surgical techniques in the literature. The main advantage of our study is to record pain scores and the level of analgesic requirements after surgery. We believe our study contributes to the current literature because it is a direct comparison of the two most common surgical techniques in a very specific population, including unilateral primary VUR patients.

\section{CONCLUSIONS}

Intravesical and extravesical ureteral reimplantation are highly effective methods to treat VUR, with success rates of up to $98 \%{ }^{6}$. On the other hand, the open intravesical technique is more invasive and causes more comorbidities than the extravesical one $^{11}$. The extravesical technique is a rather easy procedure that requires less operative time, has a shorter hospital stay, and averts gross hematuria. Those children who had extravesical surgery experienced less postoperative pain and required fewer analgesics. Both techniques are applicable in urology practice. However, both techniques could be performed by the surgeons depending on their surgical experience.

\section{COMPLIANCE WITH ETHICAL STANDARDS}

Author contributions

All authors have made substantial contributions to the article and assume full responsibility for its content; all those who have made substantial contributions to the article have been named as authors.

\section{Funding}

No financial or nonfinancial benefits have been received or will be received from any party related directly or indirectly to the subject of this article.

\section{Conflict of interest}

The authors declare that they have no conflict of interest.

\section{Ethical approval}

This is a retrospective study that was conducted at the Diyarbakır Gazi Yaşargil Training and Research Hospital, Turkey, and was approved by the Diyarbakır Gazi Yaşargil Training and Research Hospital Ethics Committee. The study is in accordance with the 1964 Helsinki Declaration and its later amendments or comparable ethical standards.

\section{Informed consent}

Informed consent was obtained from all individual participants included in the study.

\section{Author's contributions}

Cemil Aydin, MD, Assist. Prof./ Writer, Data collection, Design, Analysis. Ali Akkoc, MD, Assist. Prof./ Concept and design. Ramazan Topaktaş, MD / Acquisition of data. Aykut Bugra Sentürk, MD, Assist. Prof./ Concept and design. Zeynep Banu Aydin, MD/ Radiologic evaluation, analysis or interpretation of data. Ahmet Ürkmez, MD, Assist. Prof./ Critical revision for important intellectual content. Muhammet Yaytokgil, MD, Analysis or interpretation of data. 


\section{RESUMO}

OBJETIVO: O Refluxo Vesicoureteral (RVU) representa um dos mais importantes fatores de risco para pielonefrite aguda em crianças. Diversas técnicas intra e extravesicais já foram descritas para a correção cirúrgica do RVU. O objetivo do nosso estudo é comparar os resultados de procedimentos extravesicais e intravesicais abertos para o tratamento de RVU primário unilateral em crianças.

METODOLOGIA: Entre janeiro de 2012 e agosto de 2018, 38 crianças com RVU primário foram submetidas a cirurgia aberta de reimplante ureteral. Esses casos foram retrospectivamente revisados. As abordagens de Cohen (intravesical) e Lich-Gregoir (extravesical) foram agrupadas nos grupos A e B, respectivamente. Os grupos foram comparados quanto à idade, sexo, grau de refluxo pré-operatório, presença de sintomas no trato urinário inferior, tempo de operação, desconforto e dor, necessidade de analgésicos, duração de hematúria, complicações pós-operatórias e tempo de internação. Todos os parâmetros foram comparados estatisticamente.

RESULtAdos: No total, 38 pacientes foram incluídos neste estudo. O grupo A teve 18 pacientes e o grupo B, 20. O tempo médio de operação foi significativamente menor no grupo $B$ do que no grupo $A$. O tempo médio de internação também foi menor no grupo $B$. $O$ tempo de uso do foley uretral foi de 4,7 $\pm 0,9$ dias e $2 \pm 0$ dias $\left(p=0,000^{*}\right)$, respectivamente, para o grupo A e B. Hematúria macroscópica foi observada no grupo A. A pontuação na escala objetiva de dor foi pior após a cirurgia intravesical. A necessidade de analgésicos foi maior no grupo $A(p=0,137)$.

CONCLUSÃo: As técnicas extravesicais e intravesical de ureteroneocistostomia são igualmente bem-sucedidas e viáveis para o tratamento de RVU primário unilateral. A técnica de Cohen está associada a um período de internação mais longo e mais doloroso, hematúria e maior tempo operatório, em comparação com a técnica de Lich-Gregoir.

PALAVRAS-CHAVE: Refluxo vesicoureteral. Ureter/cirurgia. Medição da dor. Reimplante.

\section{REFERENCES}

1. Olbing I, Claësson I, Ebel KD, Seppänen U, Smellie JM, Tamminen-Möbius $T$, et al. Renal scars and parenchymal thinning in children with vesicoureteral reflux: a 5-year report of the International Reflux Study in Children (European branch). J Urol. 1992;148(5 Pt 2):1653-6.

2. Elder JS, Peters CA, Arant BS Jr, Ewalt DH, Hawtrey CE, Hurwitz RS, et al. Pediatric Vesicoureteral Reflux Guidelines Panel summary report on the management of primary vesicoureteral reflux in children. J Urol. 1997;157(5):1846-51.

3. Fanos V, Cataldi L. Antibiotics or surgery for vesicoureteric reflux in children. Lancet. 2004;364(9446):1720-2.

4. Weiss R, Duckett J, Spitzer A. Results of a randomized clinical trial of medical versus surgical management of infants and children with grades III and IV primary vesicoureteral reflux (United States). The International Reflux Study in Children. J Urol. 1992;148(5 Pt 2):1667-73.

5. Tekgul S, Dogan H, Kocvara R, Nijman JM, Radmayr C, Stein R, et al. EAUESPU guidelines on pediatric urology. In: European Association of Urology guidelines. Arnhem: European Association of Urology; 2017.

6. Austin JC, Cooper CS. Vesicoureteral reflux: surgical approaches. Urol Clin North Am. 2004;31(3):543-57.

7. King LR. The development of the management of vesico-ureteric reflux in the USA. BJU Int. 2003;92(Suppl 1):4-6.

8. Kurtz MP, Leow JJ, Varda BK, Logvinenko T, McQuaid JW, Yu RN, et al. The decline of the open ureteral reimplant in the United States: national data from 2003 to 2013. Urology. 2017;100:193-7.

9. Kobelt G, Canning DA, Hensle TW, Läckgren G. The cost-effectiveness of endoscopic injection of dextranomer/hyaluronic acid copolymer for vesicoureteral reflux. J Urol. 2003;169(4):1480-4.

10. Lapointe SP, Barrieras D, Leblanc B, Williot P. Modified Lich-Gregoir ureteral reimplantation: experience of a Canadian center. J Urol. 1998;159(5):1662-4.

11. Ellsworth PI, Merguerian PA. Detrusorraphy for the repair of vesicoureteral reflux: comparison with the Leadbetter-Politano ureteroneocystostomy. I Pediatr Surg. 1995;30(4):600-3.
12. Weiss DA, Shukla AR. The robotic-assisted ureteral reimplantation: the evolution to a new standard. Urol Clin North Am. 2015;42(1):99-109.

13. Gillies D, Lane L, Murrell D, Cohen R. Bladder spasm in children after surgery for ureteric reimplantation. Pediatric Surg Int. 2003;19(11):733-6.

14. Chen HW, Yuan SS, Lin C). Ureteral reimplantation for vesicoureteral reflux: comparison of minimally invasive extravesical with transvesical and conventional extravesical techniques. Urology. 2004;63(2):364-7.

15. Esposito C, Escolino M, Lopez M, Farina A, Cerulo M, Savanelli A, et al. Surgical management of pediatric vesicoureteral reflux: a comparative study between endoscopic, laparoscopic, and open surgery. I Laparoendosc Adv Surg Tech A. 2016;26(7):574-80.

16. Oswald I, Riccabona M, Lusuardi L, Ulmer H, Bartsch G, Radmayr C. Voiding cystourethrography using the suprapubic versus transurethral route in infants and children: results of a prospective pain scale-oriented study. J Urol. 2002;168(6):2586-9.

17. Arlen AM, Broderick KM, Travers C, Smith EA, Elmore |M, Kirsch AJ. Outcomes of complex robot-assisted extravesical ureteral reimplantation in the pediatric population. J Pediatr Urol. 2016;12(3):169.e1-6.

18. Harel M, Herbst KW, Silvis R, Makari JH, Ferrer FA, Kim C. Objective pain assessment after ureteral reimplantation: comparison of open versus robotic approach. J Pediatr Urol. 2015;11(2):82.e1-8.

19. Nabavizadeh B, Keihani S, Hosseini Sharifi SH, Kajbafzadeh AM. Insertion of a single double-J stent for bilateral open ureteral reimplantation: introducing a novel technique and assessment of feasibility. Int Urol Nephrol. 2016;48(7):1015-9.

20. Uvin P, Van Baelen A, Verhaegen J, Bogaert G. Ureteral stents do not cause bacterial infections in children after ureteral reimplantation. Urology. 2011;78(1):154-8.

21. Lee S, Jeong SC, Chung JM, Lee SD. Secondary surgery for vesicoureteral reflux after failed endoscopic injection: comparison to primary surgery. Investig Clin Urol. 2016;57(1):58-62. 